\title{
Pain and sleeping problems in the elderly
}

\author{
Dor e dificuldade para dormir em idosos
}

Élen dos Santos Alves ${ }^{1}$, Nathalia Alves de Oliveira ${ }^{1}$, Mariélli Terassi ${ }^{1}$, Bruna Moretti Luchesi ${ }^{2}$, Sofia Cristina lost Pavarini ${ }^{1}$, Keika Inouye ${ }^{3}$

DOI 10.5935/2595-0118.20190039

\section{ABSTRACT}

BACKGROUND AND OBJECTIVES: Brazil is going through changes in the sociodemographic profile leading to changes in epidemiological profile and population aging. Considering the increase of the elderly population with chronic noncommunicable disease, and the identification of chronic pain as a public health problem and its persistence associated with the worsening of the quality of sleep, the objective of this study was to identify the association between self-reported sleeping problems and the intensity of chronic pain.

METHODS: A quantitative, descriptive, cross-sectional study conducted with 187 elderly people living in one of the Family Health Unit areas of the municipality and over 60 years old. A sociodemographic characterization instrument was used with one guiding question about sleeping problems (self-reported) and the Multidimensional Pain Evaluation Scale.

RESULTS: Pain was described as moderate and intense, with a higher prevalence in the lumbar, iliac and knee regions, being significantly more intense $(\mathrm{p}=0.028)$ in the group of elderly people who have sleeping problems.

CONCLUSION: The analyzes allowed to observe an association between sleeping problems and the intensity of chronic pain. Keywords: Adaptation disorders, Elderly people, Pain, Sleep.

Élen dos Santos Alves - (Dhttps://orcid.org/0000-0001-9696-2703;

Nathalia Alves de Oliveira - (Dhttp://orcid.org/0000-0003-1665-8109;

Mariélli Terassi - Dhttps://orcid.org/0000-0002-8933-3519;

Bruna Moretti Luchesi - Dhttps://orcid.org/0000-0002-0508-0818;

Sofia Cristina Iost Pavarini - (Dhttps://orcid.org/0000-0001-9359-8600;

Keika Inouye - (Dhttp://orcid.org/0000-0003-3570-0704.

1. Universidade Federal de São Carlos, Departamento de Enfermagem, São Carlos, SP, Brasil. 2. Universidade Federal de Mato Grosso do Sul, Campus Três Lagoas, Graduação em Medicina, Três Lagoas, MS, Brasil.

3. Universidade Federal de Sáo Carlos, Departamento de Gerontologia, São Carlos, SP, Brasil

Submitted on May 21, 2019.

Accepted for publication on July 16, 2019.

Conflict of interests: none - Sponsoring sources: CAPES - Coordenação de Aperfeiçoamento de Pessoal de Nível Superior.

Correspondence to:

Rodovia Washington Luís s/n, km 235 - Caixa Postal 676

13565-905 São Carlos, SP, Brasil.

E-mail: elendutra23@gmail.com

(C) Sociedade Brasileira para o Estudo da Dor

\section{RESUMO}

JUSTIFICATIVA E OBJETIVOS: O Brasil apresenta mudanças no perfil sociodemográfico, acarretando mudanças no perfil epidemiológico e no envelhecimento populacional. Considerando o amento da população idosa com doença crônica não transmissível, e identificada a dor crônica como um problema de saúde pública e sua persistência associada à piora da qualidade do sono, este estudo teve como objetivo identificar a associação entre dificuldade para dormir autorrelatada e a intensidade da dor crônica.

MÉTODOS: Realizou-se um estudo quantitativo, descritivo de corte transversal, composto por 187 idosos com mais de 60 anos, residentes em uma das áreas de Unidade de Saúde da Família do município. Foi utilizado um instrumento de caracterização sociodemográfica com uma pergunta norteadora sobre dificuldade para dormir (autorrelatada) e a Escala Multidimensional de Avaliação da Dor.

RESULTADOS: A dor foi descrita como moderada e intensa, com maior prevalência nas regióes lombar, ilíaca e joelhos, sendo significativamente mais intensa $(p=0,028)$ no grupo de idosos que tem dificuldade para dormir.

CONCLUSÁO: As análises permitiram observar uma associação entre dificuldade para dormir e a intensidade da dor crônica.

Descritores: Dor, Idoso, Sono, Transtornos de adaptação.

\section{INTRODUCTION}

Nowadays, Brazil is changing its sociodemographic profile as a result of declining birth rates and increasing longevity ${ }^{1}$. This phenomenon that leads to population aging is aligned with the world context. In 2012, there were 810 million people with ages of 60 and over, constituting $11.5 \%$ of the global population. It is estimated that by 2050 there will be more seniors than children under the age of 15 , and the number of older people is projected to reach 2 billion in the same year, representing $22 \%$ of the world's population ${ }^{2}$. These demographic changes create important modifications in the epidemiological profile, constituting relevant changes in morbidity, mortality, and health indicators. Population aging is accompanied by increased health problems. In Brazil, the number of older people who have some chronic noncommunicable disease (NCD) increases exponentially, and they are more likely to have autonomy and independence reduction ${ }^{1}$.

Oldness is often associated with a high incidence of chronic and degenerative diseases that may compromise independence ${ }^{3}$. Many cases are accompanied by pain, and chronic pain (CP) 
is the most frequent type of complaint of the individuals $s^{4}$. CP has been associated with pathological processes and is a frequent cause of functional limitations ${ }^{5}$.

According to the Brazilian Society for the Study of Pain (SBED), pain is a warning sign and protection for the body. However, CP loses its alertness and survival function, and gets other aspects of emotional, physical, and social nature, being an abnormal and non-protective response. It can also be defined as a sensory and emotional experience - unpleasant and disproportionate, causing physical and psychic discomfort to the individual ${ }^{6}$. Pain is understood as chronic if it lasts longer than six months and is considered a disease rather than a symptom.

Pain, identified as a critical public health problem, is responsible for high health costs, reduced productivity, and quality of life $(\mathrm{QoL})^{7}$. The persistence of pain is strongly associated with symptom exacerbation and worsening sleep quality. Studies show an association between sleep quality and pain ${ }^{8}$.

Sleep is an essential life function. It acts as a repairer of vital and regulatory functions and is core to good mental health. It consists of two phases, called Non-Rapid Eye Movement (NREM) sleep and Rapid Eye Movement (REM) sleep. The NREM sleep is characterized by the absence of rapid eye movements, and is divided into four stages - I, II, III and IV, beginning with superficial sleep, followed by the three stages with increasing depth. Then the superficial phase returns until reach the deepest sleep, called REM. The first phase of sleep, NREM, is characterized by muscle relaxation, but with the maintenance of tone, progressive reduction of body movements and regular breathing. The REM sleep is characterized by the presence of rapid eye movements, we can also say that this phase is also characterized by an active brain in a paralyzed body, and irregular breathing, being in this phase the occurrence of dreams. The phases are distinct and alternate in cycles, ranging from four to six cycles in one night ${ }^{9.10}$.

The normal aging process leads to changes in sleep structure in more than half of the elderly population, negatively impacting QoL ${ }^{11}$. With advancing age, the elderly tends to sleep less, with a significant reduction in the amount and quality of sleep ${ }^{12,13}$. According to Kreling ${ }^{14}$, individuals with acute or chronic pain may present changes in sleep pattern, manifestations of irritability, and decreased ability to concentrate.

Sleep disorders occur more frequently in the elderly, affecting the quality of night sleep and the need for rest during the day. Pain, regardless of its nature, when left untreated, can result in impaired sleep patterns. However, its assessment in the elderly can be difficult considering that physiological, psychosocial, and cognitive alterations may be present ${ }^{15}$. Treatment must have as its primary target the causes, prioritizing sleep hygiene in order to improve the QoL of the elderly, with emphasis on functional capacity, sleep pattern, and even the socialization of the individual. However, pharmacological treatment has been a common practice that can have some risks such as falls, daytime sedation, cognitive decline, and alteration of sleep architecture. Thus, there is evidence that the use of sleep hygiene is a good therapeutic option with efficacy documented in the literature ${ }^{6,16,17}$. The presence of pain in the elderly is a relevant problem in the current social and health context, especially when it has influences on the sleep patterns of the elderly.

The purpose of this study was to identify the association between self-reported difficulty in sleeping and the intensity of CP.

\section{METHODS}

This research is quantitative, descriptive, and cross-sectional. Data were collected from 16 Family Health Units (USF) in the city of São Carlos (SP). The medium-sized city has a total population of 221,950 inhabitants, of these 28,868 are elderly - the equivalent of $13 \%$ of the total population ${ }^{18}$. USF coverage is of 39,768 inhabitants in urban and rural areas ${ }^{19}$. The inclusion criteria were being 60 years old or older, being registered and residing in the coverage area of one of the city's USF and presenting self-perceived CP. Data collection was performed by members of the Research Group (RG) of which the authors are part. It was made contact with the USF to identify households with at least two seniors. With a list of all names and addresses $(n=594)$, all the houses were visited by members of the RG. It was collected data from 351 seniors, as some potential subjects refused to participate, were not located, moved, or had died. All participants signed the Free Informed Consent Form (FICT).

Based on the population data, the proportion of older people and the number of individuals served by the USF of the city, it was possible to estimate the number of elderlies assisted at the USFs of Sáo Carlos (5172). It was estimated that 300 elderly would be a sample with a confidence level of $95 \%$ and a margin of error of 5.0\%. This calculation was made by the Survey Mon$k e y^{\circ}$ platform, available at <https://pt.surveymonkey.com/mp/ sample-size-calculator/\#>. Data from 351 elderly were analyzed, of these 187 had CP. The sample size corroborates literature data, as $53 \%$ of the elderly had $\mathrm{CP}^{20}$.

The elderly were divided into two groups for comparison: Group A - (GA) with sleep difficulty ( $\mathrm{n}=104)$ and Group B (GB) without sleep difficulty ( $\mathrm{n}=83)$ - from the guiding question: "Do you have sleeping difficulty?" with the answer options: "Yes" or "No". Data collection for the dependent variable "pain" was performed using the Multidimensional Pain Evaluation Scale (EMADOR). This instrument was validated for use in Brazil in 2010, and it is used for the evaluation and measurement of the sensitive, affective, and cognitive dimensions of the pain variable. Its objective is to evaluate acute and chronic pain through quantitative and qualitative analysis. The instrument has a question for intensity assessment, with scores ranging from zero to 10 points, where the higher the grade reported, the greater the intensity of pain. For the qualitative analysis, the participant chose, from 10 descriptors, the one that best represented their pain. The scale also includes a body diagram that allows the individual to show the locations affected by pain ${ }^{21}$.

All stages of this work obeyed the ethical guidelines that regulate research with human beings. Data collection started only after the approval of the Research Ethics Committee of the Federal University of São Carlos under opinion number 711.592 of 2014. 


\section{Statistical analysis}

The data obtained were entered in a database in the software Statistical Package for Social Sciences (SPSS) for Windows to perform: (a) descriptive analyzes to characterize the sociodemographic profile and pain of the elderly; (b) Pearson chi-square and Mann-Whitney tests to compare participants' sociodemographic profile and pain according to difficulty in sleeping. The $\mathrm{p}$-value to consider statistically significant difference was $\mathrm{p} \leq 0.05$.

\section{RESULTS}

The sample consisted of 187 older people with CP registered in the areas covered by the USF. Regarding sociodemographic characteristics, the sample had a mean age of $68.9 \pm 7.07$ years, predominantly female $(\mathrm{n}=151 ; 80.7 \%)$ and $88.8 \%(\mathrm{n}=166)$ lived with a partner. As for the education level, 109 (58.3\%) had attended primary school, and $18.7 \%(\mathrm{n}=35)$ had never attended school. Regarding religiosity, 114 (61\%) said they were Catholic. Regarding ethnicity, most of the elderly declared themselves white $(\mathrm{n}=131 ; 70.1 \%)$. Regarding income, 58.3\% ( $\mathrm{n}=109)$ said it was not enough.
Tables 1 and 2 show the detailed sociodemographic characteristics of the participants and the comparative analysis between the groups divided according to the sleeping.

It is noteworthy that the groups did not differ in relation to demographic variables. This pairing ensures greater control of the comparative analysis of the dependent pain variable, minimizes bias, and increases the reliability of the outcomes regarding the general research objective.

Regarding pain intensity and description, there was significant variability of responses. Moderate and severe intensities were the most reported in both groups, with severe intensity shifting to the group with sleeping difficulty, that is, the proportion of people with moderate pain was higher in the group without sleeping difficulty. On the other hand, the proportion of elderly with severe pain was higher in the group with sleeping difficulty $\left(\chi^{2}=6.508, \mathrm{gl}=1, \mathrm{p}=0.011\right)$ (Table 3).

Regarding pain descriptors, the most reported were persistent $(\mathrm{n}=138 ; 73.8 \%)$, depressing $(\mathrm{n}=104 ; 55.6 \%)$ and uncomfortable $(\mathrm{n}=173 ; 92.5 \%)$. All with significant differences between groups ( $\mathrm{p}=0.036 ; \mathrm{p}=0.003 ; \mathrm{p}=0.034$, respectively) (Table 3 ).

Regarding pain location, regions were common in both groups, with the low back, the iliac and right knee being the most re-

Table 1. Distribution of the elderly according to the characterization variables regarding sleeping difficulty and comparative analysis between groups. São Carlos, 2014

\begin{tabular}{|c|c|c|c|c|c|c|c|c|c|}
\hline \multirow[t]{2}{*}{ Variables } & \multicolumn{2}{|c|}{$\begin{array}{l}\text { No sleeping } \\
\text { difficulty (GB) }\end{array}$} & \multicolumn{2}{|c|}{$\begin{array}{l}\text { With sleeping } \\
\text { difficulty (GA) }\end{array}$} & \multicolumn{2}{|c|}{ Both groups } & \multicolumn{3}{|c|}{ Comparative analysis } \\
\hline & $\mathrm{n}$ & $\%$ & $\mathrm{n}$ & $\%$ & $\mathrm{n}$ & $\%$ & $\chi^{2 *}$ & $\mathrm{gl}$ & $p$-value \\
\hline Gender & & & & & & & 2.254 & 1 & $0.133^{\text {ns }}$ \\
\hline Female & 63 & 75.5 & 16 & 15.4 & 151 & 80.7 & & & \\
\hline Male & 20 & 24.1 & 88 & 84.6 & 36 & 19.3 & & & \\
\hline Marital status & & & & & & & 1.669 & 3 & $0.644^{\mathrm{ns}}$ \\
\hline With partner & 73 & 88 & 93 & 89.4 & 166 & 88.8 & & & \\
\hline Single & 5 & 6 & 4 & 3.8 & 9 & 4.8 & & & \\
\hline Separated & 3 & 3.6 & 2 & 1.9 & 5 & 2.7 & & & \\
\hline Widow/widower & 2 & 2.4 & 5 & 4.8 & 7 & 3.7 & & & \\
\hline Education Level & & & & & & & 6.601 & 6 & $0.359^{n s}$ \\
\hline Never attended school. & 13 & 15.7 & 22 & 21.2 & 35 & 18.7 & & & \\
\hline Literacy course & 2 & 2.4 & 5 & 4.8 & 7 & 3.7 & & & \\
\hline Primary scholl & 50 & 60.2 & 59 & 56.7 & 109 & 58.3 & & & \\
\hline Basic education & 10 & 12 & 5 & 4.8 & 15 & 8 & & & \\
\hline Technical/classic High school & 5 & 6 & 10 & 9.6 & 15 & 8 & & & \\
\hline Higher education & 3 & 3.6 & 2 & 1.9 & 5 & 2.7 & & & \\
\hline Post-graduation & 0 & 0 & 1 & 1 & 1 & 0.5 & & & \\
\hline Religion & & & & & & & 11.187 & 6 & $0.083^{\text {ns }}$ \\
\hline Catholic (a) & 54 & 65.1 & 60 & 57.7 & 114 & 61 & & & \\
\hline Evangelical (a) & 21 & 25.3 & 30 & 28.8 & 51 & 27.3 & & & \\
\hline Christian Congregation & 5 & 6 & 3 & 2.9 & 8 & 4.3 & & & \\
\hline Adventist & 1 & 1.2 & 3 & 2.9 & 4 & 2.1 & & & \\
\hline Spiritist & 0 & 0 & 7 & 6.5 & 7 & 3.7 & & & \\
\hline Umbandist & 0 & 0 & 1 & 1 & 1 & 0.5 & & & \\
\hline Does not have & 2 & 2.4 & 0 & 0 & 2 & 1.1 & & & \\
\hline
\end{tabular}


Table 1. Distribution of the elderly according to the characterization variables regarding sleeping difficulty and comparative analysis between groups. São Carlos, 2014 - continuation

\begin{tabular}{|c|c|c|c|c|c|c|c|c|c|}
\hline \multirow[t]{2}{*}{ Variables } & \multicolumn{2}{|c|}{$\begin{array}{l}\text { No sleeping } \\
\text { difficulty (GB) }\end{array}$} & \multicolumn{2}{|c|}{$\begin{array}{l}\text { With sleeping } \\
\text { difficulty (GA) }\end{array}$} & \multicolumn{2}{|c|}{ Both groups } & \multicolumn{3}{|c|}{ Comparative analysis } \\
\hline & $\mathrm{n}$ & $\%$ & $\mathrm{n}$ & $\%$ & $\mathrm{n}$ & $\%$ & $\chi^{2 *}$ & gl & $p$-value \\
\hline White & 58 & 69.9 & 73 & 70.2 & 131 & 70.1 & & & \\
\hline Black & 5 & 6 & 12 & 11.5 & 17 & 9.1 & & & \\
\hline Indigenous & 1 & 1.2 & 0 & 0 & 1 & 0.5 & & & \\
\hline Yellow/Asiatic & 0 & 0 & 0 & 0 & 0 & 0 & & & \\
\hline Sufficient income & & & & & & & 1.359 & 2 & $0.507^{\mathrm{ns}}$ \\
\hline No & 47 & 56.6 & 62 & 59.6 & 109 & 58.3 & & & \\
\hline Yes & 35 & 42.2 & 42 & 40.4 & 77 & 41.2 & & & \\
\hline
\end{tabular}

${ }^{*}$ Chi-square; ${ }^{* \star}$ Significant; ${ }^{\text {ss}}=$ Not significant.

Table 2. Descriptive and comparative analyzes of characterization variables according to sleeping difficulty. São Carlos, 2014

\begin{tabular}{|c|c|c|c|c|c|}
\hline Variables & $\begin{array}{c}\text { No sleeping } \\
\text { difficulty (GB) }\end{array}$ & $\begin{array}{l}\text { With sleeping } \\
\text { difficulty (GA) }\end{array}$ & Both groups & $U^{*}$ & $p$-value \\
\hline Age (years) & & & & 3678.00 & $0.082^{\text {ns }}$ \\
\hline Mean & 68,13 & 69.60 & 68.95 & & \\
\hline Median & 67.00 & 68.00 & 97.00 & & \\
\hline Standard deviation & 7.04 & 7.06 & 7.07 & & \\
\hline Minimum & 60 & 60 & 60 & & \\
\hline Maximum & 95 & 91 & 95 & & \\
\hline Educational level (years) & & & & 3837.00 & $0.183^{\text {ns }}$ \\
\hline Mean & 4.41 & 3.92 & 4.14 & & \\
\hline Median & 4.00 & 4.00 & 4.00 & & \\
\hline Standard deviation & 3.68 & 3.58 & 3.62 & & \\
\hline Minimum & 0.00 & 0.00 & 0.00 & & \\
\hline Maximum & 17.00 & 15.00 & 17.00 & & \\
\hline Seniors' income (Reais) & & & & 3762.00 & $0.235^{\mathrm{ns}}$ \\
\hline Mean & 815.29 & 710.33 & 756.53 & & \\
\hline Median & 724.00 & 724.00 & 724.00 & & \\
\hline Standard deviation & 949.57 & 777.66 & 856.73 & & \\
\hline Minimum & 0.00 & 0.00 & 0.00 & & \\
\hline Maximum & 6,500 & 4,500 & 6,500 & & \\
\hline Household income (Reais) & & & & 3641.00 & $0.384^{\mathrm{ns}}$ \\
\hline Mean & 2293.32 & 2265.20 & 2277.45 & & \\
\hline Median & 1980.00 & 1604.00 & 1848.00 & & \\
\hline Standard deviation & 1249.66 & 1576.682 & 1439.55 & & \\
\hline Minimum & 724.00 & 724.00 & 724.00 & & \\
\hline Maximum & 6,500 & 10000.00 & 10000.00 & & \\
\hline
\end{tabular}

${ }^{*}$ Mann-Whitney; ${ }^{* *}$ Significant; ${ }^{\text {ns }}=$ Not significant. 
Table 3. Descriptive and comparative analyzes of pain and according to sleeping difficulty. São Carlos, 2014

\begin{tabular}{|c|c|c|c|c|c|c|c|c|c|}
\hline Variables & \multicolumn{2}{|c|}{$\begin{array}{l}\text { No sleeping } \\
\text { difficulty (GB) }\end{array}$} & \multicolumn{2}{|c|}{$\begin{array}{l}\text { With sleeping } \\
\text { difficulty (GA) }\end{array}$} & \multicolumn{2}{|c|}{ Both groups } & \multicolumn{3}{|c|}{ Comparative analysis } \\
\hline Classification of pain & & & & & & & 6.508 & 1 & $0.011^{\star \star}$ \\
\hline 0 & 4 & 4.8 & 1 & 1.0 & 5 & 2.7 & & & \\
\hline \multicolumn{10}{|l|}{ Light (1 to 3 ) } \\
\hline 3 & 3 & 3.6 & 6 & 5.8 & 9 & 4.8 & & & \\
\hline \multicolumn{10}{|l|}{ Moderate (4 to 6) } \\
\hline 4 & 7 & 8.4 & 4 & 3.8 & 11 & 5.9 & & & \\
\hline 5 & 18 & 21.7 & 25 & 24.0 & 43 & 23.0 & & & \\
\hline 6 & 12 & 14.5 & 7 & 6.7 & 19 & 10.2 & & & \\
\hline 9 & 5 & 6.0 & 9 & 8.7 & 14 & 7.5 & & & \\
\hline \multicolumn{10}{|l|}{ Unbeatable (10) } \\
\hline 10 & 7 & 8.4 & 15 & 14.4 & 22 & 11.8 & & & \\
\hline Total & 83 & 100 & 104 & 100 & 187 & 100 & & & \\
\hline Pain descriptors & $\mathrm{n}$ & $\%$ & $\mathrm{n}$ & $\%$ & $\mathrm{n}$ & $\%$ & $\chi^{2 \star}$ & $\mathrm{gl}$ & $p$-value ${ }^{*}$ \\
\hline Depressing & & & & & & & 9.060 & 1 & $0.003^{\star \star}$ \\
\hline Yes & 36 & 43.4 & 68 & 65.4 & 104 & 55.6 & & & \\
\hline No & 47 & 56.6 & 36 & 34.6 & 83 & 44.4 & & & \\
\hline Persistent & & & & & & & 4.378 & 1 & $0.036^{\star *}$ \\
\hline Yes & 55 & 66.3 & 83 & 79.8 & 138 & 73.8 & & & \\
\hline Harmful & & & & & & & 0.309 & 1 & $0.578^{\mathrm{ns}}$ \\
\hline Yes & 51 & 61.4 & 68 & 65.4 & 119 & 63.6 & & & \\
\hline No & 32 & 38.6 & 36 & 34.6 & 68 & 36.4 & & & \\
\hline Painful & & & & & & & 2.170 & 1 & $0.141^{\mathrm{ns}}$ \\
\hline Yes & 69 & 83.1 & 94 & 90.4 & 163 & 87.2 & & & \\
\hline No & 14 & 16.9 & 10 & 9.6 & 24 & 12.8 & & & \\
\hline Unbearable & & & & & & & 2.763 & 1 & $0.096^{\mathrm{ns}}$ \\
\hline Yes & 41 & 49.4 & 64 & 61.5 & 105 & 56.1 & & & \\
\hline No & 42 & 50.6 & 40 & 38.5 & 82 & 43.9 & & & \\
\hline Frightening & & & & & & & 0.541 & 1 & $0.462^{\mathrm{ns}}$ \\
\hline Yes & 23 & 27.7 & 34 & 32.7 & 57 & 30.5 & & & \\
\hline No & 60 & 72.3 & 70 & 67.3 & 130 & 69.5 & & & \\
\hline Cruel & & & & & & & 1.517 & 1 & $0.218^{\mathrm{ns}}$ \\
\hline Yes & 34 & 41 & 52 & 50 & 86 & 46 & & & \\
\hline No & 49 & 59 & 52 & 50 & 101 & 54 & & & \\
\hline Uncomfortable & & & & & & & 4.484 & 1 & $0.034^{\star \star}$ \\
\hline Yes & 73 & 88 & 100 & 96.2 & 173 & 92.5 & & & \\
\hline No & 10 & 12 & 4 & 3.8 & 14 & 7.5 & & & \\
\hline Total & 83 & 100 & 104 & 100 & 187 & 100 & & & \\
\hline
\end{tabular}

${ }^{*}$ Chi square; ${ }^{* * *}$ Linear-by-Linear Association; ${ }^{* *}$ Significant; ${ }^{\text {ns }}=$ Not significant. 


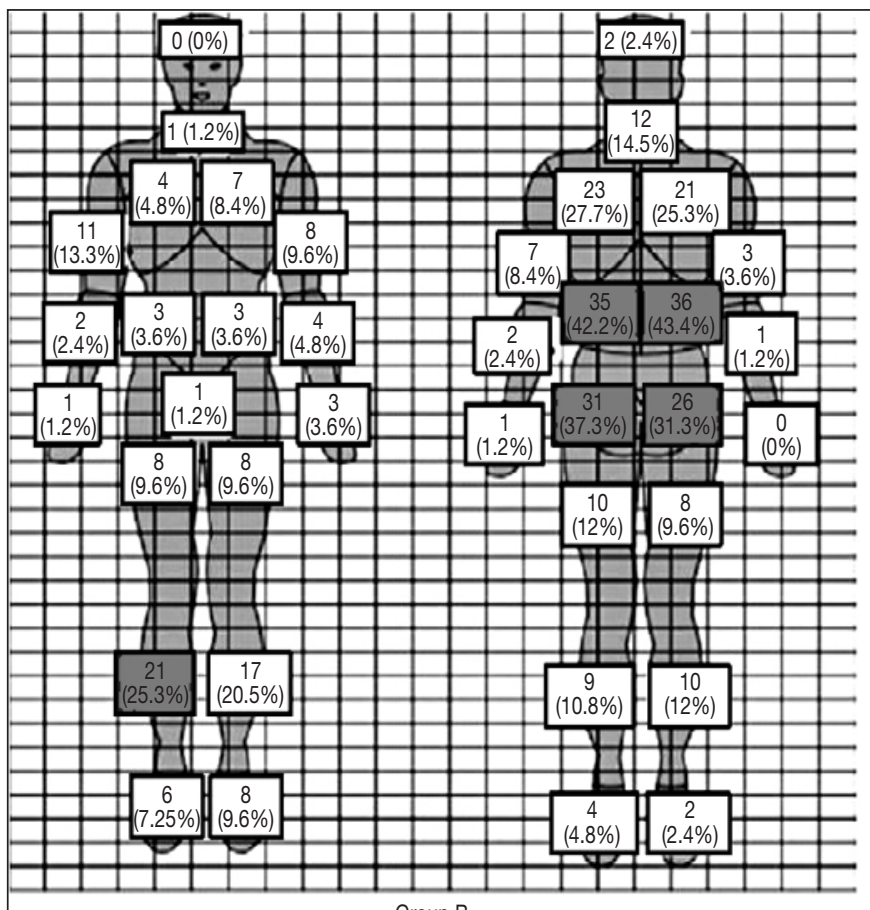

Group B

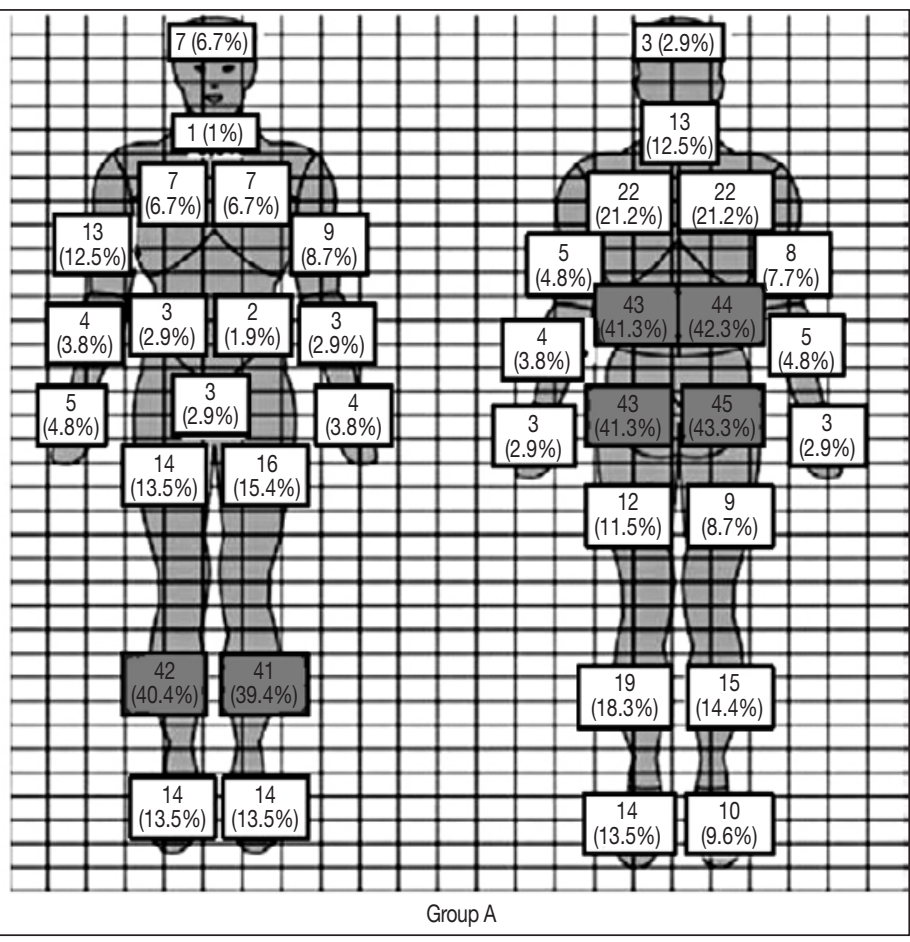

Figure 1. Pain location in the elderly

Table 4. Descriptive and comparative analyzes of pain and sleeping difficulty. São Carlos, 2014

\begin{tabular}{|c|c|c|c|c|c|c|}
\hline & & No sleeping difficulty (GB) & With sleeping difficulty (GA) & Both groups & $U^{*}$ & P-value \\
\hline \multirow{4}{*}{$\begin{array}{l}\text { Intensity } \\
\text { of pain }\end{array}$} & & & & & 3516.50 & $0.028^{* *}$ \\
\hline & Mean & 5.90 & 6.82 & 6.41 & & \\
\hline & Standard deviation & 2.61 & 2.21 & 2.43 & & \\
\hline & Minimum & 0 & 0 & 0 & & \\
\hline
\end{tabular}

* Mann-Whitney; ${ }^{* \star}$ Significant.

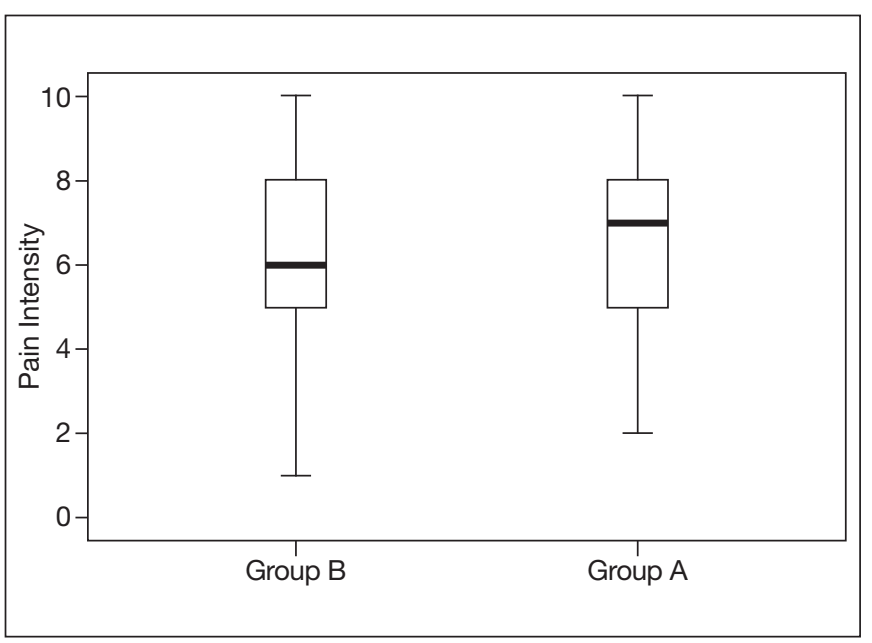

Figure 2. Comparison of pain intensity between groups of elderly with and without sleeping difficulty

Group $B=$ no sleeping difficulty; Group $A$ = with sleeping difficulty. ferred sites, varying only in the group with sleeping difficulty, where the left knee was also pointed (Figure 1). However, the pain was significantly more intense in the group that has a sleeping problem $(U=3516.50, \mathrm{p}=0.028)$, a fact that confirms the study hypothesis and the association between the study variables (Table 4 and Figure 2).

\section{DISCUSSION}

The mean age of the sample was of 68.9 years, mostly women $(80.7 \%)$ living with partners $(88.8 \%)$, depicting the typical profile of the literature. According to Augusti, Falsarella, and Coim$\mathrm{bra}^{22}$, national and international studies have presented a female profile in the population over 60 years old, a fact attributed to the greater acceptance by women concerning health treatments throughout their lives and self-care conditions. There was a predominance of younger elderly in this research, a condition that corroborates other studies ${ }^{23,24}$. 
As for the education level, only $58.3 \%$ of the elderly had completed primary school, and $18.7 \%$ of respondents had never attended school. In our country, studies indicate that the low education level of the elderly can be explained by the culture of the time when they grew up. In the past, the level of education was not as relevant as the need to work the land or learn to do chores, as well as the socioeconomic conditions that made it hard to attend school ${ }^{23}$.

The Catholic religion was predominant (61\%). This was expected, because according to the Brazilian Institute of Geography and Statistics ${ }^{1}$ (IBGE), in the 2010 census, the Brazilian population is made up of $65 \%$ of Catholics. Regarding the income in which $58.3 \%$ of the elderly said they were not satisfied, studies conducted with Brazilian elderly point in the same direction. In general, income is considered low, indicating it as the primary source of home maintenance ${ }^{12,25,26}$.

CP may be associated with a negative image and pathological processes that may or may not accompany the aging process. Its prolongation for months or years can cause dependence. However, location and intensity vary influencing functional capacity ${ }^{5,27}$. A CP study, conducted in the state of São Paulo with an elderly population, found a prevalence of $30 \%$ on low back pain, $54.5 \%$ on regional or one body segment pain and $14.1 \%$ generalized pain $^{28}$. Another study, conducted in the state of Bahia, with 68 institutionalized elderly, pointed out the occurrence of pain in $73.3 \%$ of the sample, and $51.7 \%$ described it as severe pain, indicating lower limbs as the most common places $(47.7 \%)$, and the spine $(25 \%)^{4}$. A study with 1,271 elderly residents of São Paulo, reported that $58.45 \%$ of the elderly referred to the low back region as the most frequent location of pain, data that corroborate those presented in this study ${ }^{29}$. Celich and Galon ${ }^{30}$ pointed to the lumbar spine $(44.4 \%)$, followed by the leg region $(40.7 \%)$ and knee joint $(25.9 \%)$ as the regions with the highest prevalence of CP among the elderly. The same study showed a lower incidence of pain in the toes, ankle joint (7.4\%), cephalic region, chest and abdomen (3.7\%), which are aligned with the data found in this study.

A research conducted in the city of Campinas showed a positive association between back pain and poor sleep ${ }^{31}$. In a small town in the northern region of the state of Paraná, in 2013, a qualitative study conducted with older people with $\mathrm{CP}$ observed the presence of hope for the cure of this pain, followed by the feeling of conformity and powerlessness ${ }^{32}$.

$\mathrm{CP}$ has been considered an impacting factor in the life of the elderly, with a probable relationship between pain and difficulty in falling asleep. Ferretti et al. ${ }^{33}$ in order to evaluate the quality of sleep in 385 elderly, with and without chronic pain, identified that $58.18 \%$ of the elderly had CP, and $57.59 \%$ scored poor sleep quality., of the elderly with CP, $48.66 \%$ reported moderate pain intensity, in contrast to the elderly without CP (56.52\%) who had good sleep quality.

A study conducted in São Luís, MA, with 50 elderly, identified the negative influence of $\mathrm{CP}$ on $\mathrm{QoL}$ of the respondents, noting a strong relationship with fatigue, sleep disorders and dependence on treatments or drugs $s^{34}$.
Monteiro and Ceolim ${ }^{35}$ described the quality of sleep at home and hospitalization of a sample of 160 elderly residents in a city in the countryside of São Paulo state. During hospitalization, the scores of the visual analog sleep scales (VAS-Sleep), regarding disturbance (less than 300), supplementation (less than 100) and effectiveness (greater than 300), indicate satisfactory sleep quality and moderate sleepiness during daytime. However, the authors warn that hospitalized individuals have an altered routine and take several drugs that may affect the variable. At home, the same sample had poor quality sleep (70\%) according to the Pittsburg Sleep Quality Index (PSQI) scores. Waking up at night $(80.0 \%)$, getting up to urinate $(77.5 \%)$ and pain $(33.1 \%)$ were frequently indicated as causes of sleep fragmentation. Although fragmentation is not positive, it was self-perceived as normal among respondents, since $62.5 \%$ of the elderly said they sleep "well" at home.

A descriptive study, conducted in João Pessoa, PB, with the objective of evaluating the characteristics of the sleep pattern of the elderly assisted at the geriatric outpatient clinic of a university hospital $(n=100)$, observed that $46 \%$ of the elderly had very altered sleep according to the scores for the Mini-Sleep Questionnaire. Also, the elderly reported "often," "very often" or "always" waking up at night (71\%), having a restless sleep (33\%), snoring $(33 \%)$ and not going back to sleep if they wake up $(33 \%)$. However, $57 \%$ of the sample rated their sleep pattern as good ${ }^{36}$.

Chen et al. ${ }^{37}$ evaluated the relationship between pain intensity and distribution and sleeping difficulty in the elderly. Of the 765 participants, with 64 years and over, a prevalence of sleep problems was observed according to the Brief Pain Inventory (BPI), ranging from $17.8 \%$ to $37.0 \%$ respectively for the lowest to highest quartiles of pain. With the analysis adjusted, the pain was strongly associated with sleep problems, concluding that widespread, moderate to severe pain is strongly associated with sleeping difficulty in the elderly.

Dutch longitudinal data from the Doetinchem Cohort Study, obtained from four self-reported pain measurements taken every five years with a sample of 3485 adults, aged 25-71 to 4086 years concluded that individuals with shorter sleep period, smoking, obesity, and poor perception of mental health are more prone to pain $^{38}$. Accordingly, the PAINEL Study, derived from the FIBRA Network Study, conducted in the city of Belo Horizonte, with 378 participants over 60 years, among the findings, found that individuals with disabling low back pain were more likely to have shorter sleep time ${ }^{39}$.

In general, the manifestation of response to the pain of individuals may cause changes in sleep pattern and other physio-pathological processes, considering an association between pain and adequate sleep $\mathrm{p}^{14,27}$.

Regarding the limitations of the study, since this research was based on self-report, it would be interesting for future studies to use multi-parametric examinations and tests to assess sleep disorders.

The results obtained during the study showed an association between pain and sleeping in the elderly, and corroborates the scientific literature, elucidating practices and interventions for working with the elderly. 


\section{CONCLUSION}

Comparative analyses of the present study show that there is a significant association between self-reported sleeping difficulty and the intensity of CP.

\section{REFERENCES}

1. IBGE. [internet]. Censo demográfico 2010. Disponível em: www.censo2010.ibge. gov.br.

2. Ministério dos direitos humanos (Brasil), Secretaria dos Direitos Humanos (SDH). Brasília/DF. [acesso em 2017, dez]. Disponível em: www.sdh.gov.br.

3. Machado WD, Gomes DF, Freitas MC, Moreira AC. Idosos com doenças crônicas não transmissíveis: um estudo em grupos de convivência. ReonFacema; 2017;3(2):445-51.

4. Reis LA, Torres GV. Influência da dor crônica na capacidade funcional de idosos institucionalizados. Rev Bras Enferm. 2011;64(2):274-80.

5. Dellaroza MS, Pimenta CA, Duarte YA, Lebrão ML. [Chronic pain among elderly residents in Săo Paulo, Brazil: prevalence, characteristics, and association with functional capacity and mobility (SABE Study)]. Cad Saude Publica. 2013;29(2):325-34. Portuguese.

6. Barbosa MH, Bolina AF, Tavares JL, Cordeiro AL, Luiz RB, de Oliveira KF. Sociodemographic and health factors associated with chronic pain in institutionalized elderly]. Rev Lat Am Enfermagem. 2014;22(6):1010-16. English, Portuguese, Spanish.

7. Ferreira P, Repolho M, Ribeiro MJ, Sepodes B. Diagnóstico e abordagem terapêutica da osteoartrite. Rev Port Farmacoter. 2012;4(1):15-28.

8. Freire ME, Sawada NO, de França IS, da Costa SF, Oliveira CD. [Health-related quality of life among patients with advanced cancer: an integrative review]. Rev Esc Enferm USP. 2014;48(2):357-67. Portuguese.

9. Fernandes RM. O sono normal. Medicina. 2006;39(2):157-68

10. Gomes MM, Quinhones MS, Engelhardt E. Neurofisiologia do sono e aspectos farmacoterapêuticos dos seus transtornos. Rev Bras Neurol. 2010;46(1):5-15.

11. Geib LT, Cataldo Neto A, Wainberg R, Nunes ML. Sono e envelhecimento. Rev Psiquiatr. 2003;25(3):453-65.

12. Virtuoso Júnior JS, Guerra RO. [Factors associated to functional limitations in elderly of low income]. Rev Assoc Med Bras. 2008;54(5):430-5. Portuguese.

13. Linden Junior E, Trindade JL. Avaliaçâo da qualidade de vida de idosos em um município do Sul do Brasil. Rev Bras Geriatr Gerontol. 2013;16(3):473-9.

14. Kreling MC, da Cruz DA, Pimenta CA. [Prevalence of chronic pain in adult workers]. Rev Bras Enferm. 2006;59(4):509-13. Portuguese.

15. Oliveira DN, Gorreis TF, Creutzberg M, Santos BR. Diagnósticos de enfermagem em idosos de instituiçấo de longa permanência. Rev Cien Saúde. 2008;1(2):57-63.

16. Scoralick FM, Camargos EF, Freitas MP, Nóbrega OT. [Outpatient treatment of Sleep disorders in Alzheimer patients]. Einstein. 2015;13(3):430-4. English, Portuguese.

17. Martinez D, Lenz Mdo C, Menna-Barreto L. Diagnosis of circadian rhythm Sleep disorders. J Bras Pneumol. 2008;34(3):173-180. English, Portuguese.

18. Atlas do Desenvolvimento Humano no Brasil. Perfil do município de Săo Carlos, SP. [acesso em 2017 jan]. Disponível em: http://atlasbrasil.org.br/2013/pt/perfil_m/ sao-carlos_sp.

19. Prefeitura Municipal de São Carlos. Programa Saúde da Família - PSF. [acesso em 2014, nov]. Disponível em: www.saocarlos.sp.gov.br/index.php/saude/115417-programa-saude-da-familia-psf.html.
20. Hemmingsson ES, Gustafsson M, Isaksson U, Karlsson S, Gustafson Y, Sandman PO, et al. Prevalence of pain and pharmacological pain treatment among old people in nursing homes in 2007 and 2013. Eur J Clin Pharmacol. 2018;74(4):483-8.

21. Sousa FA, Pereira LV, Cardoso R, Hortense P. Muldimensional pain evaluation scale. Rev Lat Am Enfermagem. 2010;18(1):3-10.

22. Augusti AC, Falsarella GR, Coimbra AM. Análise da síndrome da fragilidade em idosos na atenção primária-estudo transversal. Rev Bras Med Fam Comunidade. 2017;12(39):1-9.

23. Mansano-Schlosser TC, dos Santos AA, Camargo-Rossignolo Sde O, Freitas DC, Lorenz VR, Ceolim MF. [Institutionalized elderly: chronological organization of daily routines and sleep quality]. Rev Bras Enferm. 2014;67(4):610-6. Portuguese.

24. Sousa AI, Silver LD. Perfil sociodemográfico e estado de saúde auto-referido entre idosas de uma localidade de baixa renda. Esc Anna Nery Rev Enferm. 2008;12(4):706-16.

25. Jóia LC, Ruiz T, Donalísio MR. Grau de satisfaçáo com a saúde entre idosos do Município de Botucatu, Estado de São Paulo, Brasil. Epidemiol Serv Saúde. 2008;17(3):187-94

26. Wanderbroocke ACNS, Wiedemann A, Bussolin C. Participaçăo social e familiar de idosas vinculadas a um grupo de convivência de uma comunidade de Baixa renda em Curitiba-PR. Salud \& Sociedad. 2015;3(6):212-22.

27. Andrade FA, Pereira LV, Sousa FA. [Pain measurement in the elderly: a review]. Rev Lat Am Enfermagem. 2006;14(2):271-6.

28. Lima MG, Barros MB, César CL, Goldbaum M, Carandina L, Ciconelli RM. Impact of chronic disease on quality of life among the elderly in the state of Săo Paulo, Brazil: a population-based study. Rev Panam Salud Publica, 2009;25(4):314-21.

29. Cruz HM, Pimenta CA, Dellarozza MS, Braga PE, Lebrão ML, Duarte YA. Quedas em idosos com dor crônica: prevalência e fatores associados. Rev Dor. 2011;12(2):108-14.

30. Celich KLS, Galon C. Dor crônica em idosos e sua influência nas atividades da vida diária e convivência social. Rev Bras Geriatr Gerontol. 2009;12(3):345-59.

31. Lima MG, Bergamo Francisco PM, de Azevedo Barros MB. Sleep duration pattern and chronic diseases in Brazilian adults (ISACAMP, 2008/09). Sleep Med. 2012;13(2):139-44.

32. Oliveira CH, Martins EA, Montezeli JH, Souza TG, Dellaroza MS. Compreendendo a vivência dos idosos com dor crônica: a luz da teoria de Callista Roy. Cienc Cuid Saude. 2017;16(1):1-8.

33. Ferretti F, Santos DT, Giuriatti L, Gauer AP, Teo CR. Sleep quality in the elderly with and without chronic pain. BrJP. 2018;1(2):141-6.

34. Cunha LL, Mayrink WC. Influência da dor crônica na qualidade de vida em idosos. Rev Dor, 2011;12(2):120-4

35. Monteiro NT, Ceolim MF. Quality of sleep of the aged at home and in hospital. Texto e Contexto Enfermagem, 2014;23(2): 356-64.

36. Barbosa KT, Oliveira FM, Oliveira, SM, Gomes MO, Fernandes M. Qualidade do sono em pacientes idosos em atendimento ambulatorial. Rev Enferm UFPE. 2016;10(Suppl 2):756-61

37. Chen Q, Hayman LL, Shmerling RH, Bean JF, Leveille SG. Characteristics of chronic pain associated with sleep difficulty in the older population: the Maintenance of Balance, Independent Living, Intellect, and Zest in the Elderly (MOBILIZE) Boston Study. J Am Geriatr Soc. 2011;59(8):1385-92.

38. Picavet HS, Verschuren WM, Groot L, Schaap L, van Oostrom SH. Pain over the adult life course: 15 year-pain trajectories-the Doetinchem Cohort Study. Eur J Pain. 2019. [Epub ahead of print].

39. Machado LA, Viana JU, Silva S L, Couto FG, Mendes LP, Ferreira PH, Dias RC. Correlates of a recent history of disabling low back pain in community-dwelling older persons. Clin J Pain. 2018;34(6):515-24. 